\title{
PENGARUH KONSENTRASI PATI UBI TALAS (Colocasia esculenta) DAN JENIS PLASTICIZER TERHADAP KARAKTERISTIK BIOPLASTIK
}

The Effect of the Concentration of Taro Tuber Starch (Colocasia esculenta) and Plasticizer Type on The Characteristics of Bioplastics

\author{
Farida Unggul Situmorang, Amna Hartiati", Bambang Admadi Harsojuwono \\ PS Teknologi Industri Pertanian, Fakultas Teknologi Pertanian, Universitas Udayana, Kampus Bukit \\ Jimbaran, Badung, Kode pos : 80361; Telp/Fax : (0361) 701801.
}

Diterima 17 Mei 2019 / Disetujui 01 Juli 2019

\begin{abstract}
This study aims to know the effect of the concetration of taro tuber starch and plasticizer type and their interactions on the characteristics of bioplastics, and to determine the concentration of taro tuber starch and plasticizer type which produces bioplastics with the best characteristics. The research used factorial randomized block design. The first factor is the concentration of taro tuber starch consisting of 3 levels 5,6 and $7 \%(w / w)$. The second factor is the plasticizer type consisting of 3 levels that is glycerol, sorbytol and mixture plasticizer glycerol and sorbitol (1:1). Each treatment are grouped into two time-based of making bioplastics so there are 18 experimental units. Variabels observed tensile strength, elongation at break, Young's modulus, swelling, biodegradation and FTIR. The data obtained were analyzed of variant and test Tukey's. The result showed that the concentration of taro tuber starch and type of plasticizer had a very significant effect on tensile strength, elongation at break, Young's Modulus and swelling but the type of plasticizer had no significant effect on biodegradation. Interaction between treatments has a very significant effect on Young's Modulus and swelling, a significant effect on tensile strength and no significant effect on elongation at break and biodegradation. The concentration of starch 6\% with plasticizer glycerol produces the best characteristics of bioplastics with tensile strength $2.270 \pm 0.057 \mathrm{MPa}$, elongation at break $14.5 \pm 0.01 \%$, Young's modulus $15.683 \pm 1.155 \mathrm{MPa}$, swelling $29.88 \pm 1.02 \%$ and biodegradability 6-7 days. FTIR analysis proved the existence of hydroxyl $(\mathrm{O}-\mathrm{H})$, carbonyl $(\mathrm{C}=\mathrm{O}), \mathrm{C}=\mathrm{C}$ aromatic, carboxyl $(\mathrm{C}-\mathrm{O}), \mathrm{C}-\mathrm{H}$ aromatic, and hydrocarbons $-\left(\mathrm{CH}_{2}\right) \mathrm{n}$ in the bioplastic.
\end{abstract}

Keywords: Bioplastics, concentration of taro tuber starch, glycerol, sorbytol

*Korespondensi Penulis:

Email : amnahartiati@unud.ac.id 


\section{PENDAHULUAN}

Bioplastik adalah plastik yang dapat digunakan layaknya plastik konvensional, terbuat dari bahan-bahan alami dan akan hancur terurai oleh mikroorganisme dalam tanah sehingga disebut sebagai plastik yang ramah lingkungan (Agustin dan Padmawijaya, 2016). Bahan-bahan yang digunakan dalam pembuatan bioplastik adalah senyawa-senyawa polimer yang terdapat pada tanaman seperti pati, selulosa dan lignin serta pada hewan seperti kasein, kitin dan kitosan (Averous, 2004). Pada penelitian dilakukan preparasi bioplastik menggunakan bahan baku pati yang berasal dari ubi talas serta plasticizer gliserol dan sorbitol. Ubi talas digunakan sebagai bahan baku bioplastik agar nilai ekonomi dari ubi talas meningkat. Penelitian sebelumnya menunjukkan bahwa kandungan pati pada talas cukup tinggi yaitu mencapai $80 \%$ (Rahmawati et al., 2012).

Keberhasilan pembuatan bioplastik dipengaruhi oleh beberapa faktor, diantaranya konsentrasi pati dan jenis pemlastis (plasticizer). Setiani et al. (2013) menyatakan bahwa penggunaan pati dengan konsentrasi yang tinggi menyebabkan tingginya penyerapan air sehingga ketahanan air juga rendah. Liu dan Han (2005) menjelaskan bahwa peningkatan kadar pati sampai dengan $10 \%$ ternyata menghasilkan bioplastik yang terlalu kaku. Sementara itu, Dai et al. (2010) melaporkan bahwa jenis plasticizer yang ditambahkan pada larutan pati mempengaruhi karakteristik plastik yang dihasilkan, terutama pada stabilitas fisik dan mekanik. Penambahan plasticizer dapat mengurangi kerapuhan, meningkatkan fleksibilitas serta ketahanan film (Hidayati et al., 2015). Plasticizer yang paling banyak digunakan adalah gliserol dan sorbitol karena bersifat stabilitas dan tidak beracun (Hidayati et al., 2015). Selain itu, penggunaan pemlastis gliserol dan sorbitol lebih unggul karena titik didihnya yang tinggi menyebabkan pemlastis ini tidak menguap dalam proses dibandingkan dengan plasticizer lainnya seperti dietilena glikol monometil eter (DEGME), etilena glikol (EG), dietilena glikol (DEG), trietilena glikol (TEG) dan tetraetilena glikol (TEEG). Gliserol dan sorbitol merupakan plasticizer yang berfungsi untuk meningkatkan elastisitas dengan mengurangi derajat ikatan hidrogen dan meningkatkan jarak antar molekul dari polimer (Sinaga et al., 2014).

Penelitian sebelumnya oleh Setiani et al. (2013) dalam preparasi edible film dari poliblend pati sukun-kitoson (6:4) dengan plasticizer sorbitol menghasilkan kuat tarik sebesar 16,34 $\mathrm{MPa}$, perpanjangan saat putus 6,00\% dan Modulus young 2,72 MPa. Akan tetapi bioplastik yang dihasilkan memiliki sifat mekanik dan daya serap air yang masih rendah yaitu sebesar $212,98 \%$. Sementara itu, Harsojuwono dan Arnata (2016) melakukan penelitian tentang variasi konsentrasi tapioka dan perbandingan campuran pemlastis terhadap karakteristik bioplastik. Hasil penelitian tersebut menunjukkan bioplastik terbaik yang dihasilkan yaitu pada penggunaan konsenrasi pati $6 \%$ dengan perbandingan campuran pemlastis gliserol :sorbitol (100:0)\% menghasilkan nilai kuat tarik $930 \mathrm{MPa}$, perpanjangan saat putus 18,75\% dan Modulus Young $50 \mathrm{MPa}$. Pada penelitian ini penggunaan masing-masing plasticizer (gliserol dan sorbitol) secara terpisah belum diketahui.

Penelitian tentang konsentrasi pati ubi talas dengan penggunaan plasticizer (gliserol dan sorbitol) secara terpisah maupun campuran dalam pembuatan bioplastik belum diketahui. Oleh karena itu, perlu dicari konsentrasi pati dan jenis plasticizer dalam pembuatan bioplastik berbahan baku pati ubi talas. Penelitian ini bertujuan untuk mengetahui pengaruh konsentrasi pati ubi talas dan jenis plasticizer serta interaksinya dan menentukan konsentrasi pati dan jenis 
plasticizer yang paling tepat untuk menghasilkan bioplastik dengan karakteristik terbaik.

\section{METODE PENELITIAN}

\section{Alat dan Bahan}

Alat yang digunakan untuk penelitian ini adalah pisau, baskom, telenan, kain kasah, kertas saring, blender, ayakan 80 mesh, oven, neraca analitik, pipet tetes, batang pengaduk, termometer, beaker glass $100 \mathrm{~mL}$, hot plate, cetakan teflon diameter $20 \mathrm{~cm}$, alat uji mekanik plastik (Tensile Strength ZP recorder $50 \mathrm{~N}$ Imada dan komputer) mengacu pada ASTM D638 dan alat uji FTIR (IR Prestige-21).

Bahan yang digunakan dalam penelitian ini adalah ubi talas jenis Belitung (Xanthosoma sagittifolium) dengan umur ubi 10 bulan setelah tanam yang diperoleh dari pasar Kedonganan, asam asetat glasial $\left(\mathrm{CH}_{3} \mathrm{COOH}\right)$ 96\% (emsure), aquades (air suling) serta gliserol dan sorbitol murni $99 \%$ (pro analyst) dari CV. Makmur, Malang.

\section{Rancangan Percobaan}

Penelitian ini menggunakan Rancangan Acak Kelompok (RAK) faktorial dengan 2 faktor. Faktor I yaitu konsentrasi pati yang terdiri dari 3 taraf yaitu: 5, 6 dan 7\%. Faktor II yaitu jenis plasticizer yang terdiri dari tiga taraf yaitu: gliserol, sorbitol serta campuran plasticizer gliserol dan sorbitol (1:1). Berdasarkan faktor di atas diperoleh 9 kombinasi perlakuan yang masing-masing perlakuan akan dikelompokkan dalam 2 kelompok berdasarkan waktu pembuatan bioplastik sehingga terdapat 18 unit percobaan. Data yang diperoleh dianalisis keragamannya (ANOVA) dan dilanjutkan dengan uji Beda Nyata Jujur (BNJ) menggunakan perangkat lunak Minitab 17.

\section{Pelaksanaan Penelitian}

Ubi talas dikupas dan dicuci hingga bersih, kemudian dipotong-potong kecilkecil dan ditimbang. Selanjutnya, direndam dalam air biasa selama \pm 20 menit. Ubi talas dihancurkan dengan blender dengan perbandingan air dan bahan (4:1). Setelah itu, disaring untuk mendapatkan filtratnya, kemudian didiamkan selama 24 jam. Air dan patinya dipisahkan, sehingga diperoleh pati basah. Pati basah tersebut dioven dengan suhu $80 \pm 1^{\circ} \mathrm{C}$ selama 4 jam. Setelah itu diblender dan diayak dengan pengayakan 80 mesh.

Pembuatan Bioplastik dilakukan dengan penimbangan pati ubi talas dengan konsentrasi sesuai perlakuan $(5,6,7 \% \mathrm{~b} / \mathrm{b})$ dimasukkan kedalam beaker glass, kemudian ditambahkan larutan Asam asetat $\left(\mathrm{CH}_{3} \mathrm{COOH}\right)$ Glasial $1 \%$ sampai masingmasing larutan 99 gram dan diaduk sampai homogen. Setelah itu kedalam campuran masing-masing ditambahkan plasticizer sebanyak $1 \%$ sesuai perlakuan sehingga total masing-masing larutan adalah $100 \mathrm{~g}$. Selanjutnya larutan campuran dipanaskan pada hot plate dan diaduk dengan batang pengaduk pada suhu $75 \pm 2^{\circ} \mathrm{C}$ selama 7 menit yang dikontrol dengan menggunakan termometer sampai campuran membentuk gel. Gel yang terbentuk kemudian dicetak diatas cetakan teflon berdiameter $20 \mathrm{~cm}$ dan dikeringkan pada oven dengan suhu $60 \pm 1^{\circ} \mathrm{C}$ selama 10 jam. Lapisan plastik yang terbentuk kemudian didinginkan pada suhu ruang selama 24 jam hingga bioplastik dapat dilepas dari cetakan

\section{Variabel yang diamati}

Variabel yang diamati terdiri dari kuat tarik (Tensile strength) (Gibson, 1994), perpanjangan saat putus (elongation at break) (Gibson, 1994), elastisitas (Modulus young) (Gibson, 1994), uji pengembangan tebal (Nahwi, 2016), biodegradasi (Nurdini et al., 2018) serta analisis gugus fungsi dengan FTIR. Perlakuan terbaik ditentukan berdasarkan nilai kuat tarik tertinggi. 


\section{HASIL DAN PEMBAHASAN}

\section{Kuat Tarik (Tensile Strength)}

Berdasarkan hasil analisis keragaman menunjukkan bahwa konsentrasi pati dan jenis plasticizer berpengaruh sangat nyata $(\mathrm{p}<0,01)$ dan interaksinya berpengaruh nyata $(\mathrm{p}<0,05)$ terhadap kuat tarik bioplastik dari pati ubi talas. Nilai kuat tarik bioplastik pati ubi talas berkisar antara $0,595 \pm 0,120$ 2,270 $\pm 0,057 \mathrm{MPa}$ yang dapat dilihat pada Tabel 1.
Tabel 1 menunjukkan bahwa nilai kuat tarik tertinggi $(2,270 \pm 0,057 \mathrm{MPa})$ dari bioplastik ubi talas terdapat pada konsentrasi pati $6 \%$ dengan plasticizer gliserol. Hal tersebut dikarenakan campuran (bioplastik pati-gliserol) menyebabkan molekul-molekul pemlastis membentuk ikatan rantai cabang maupun crosslink (anyaman) sehingga plastik semakin homogen dan strukturnya rapat yang menyebabkan kuat tarik semakin meningkat.

Tabel 1. Nilai kuat tarik (MPa) bioplastik dari pati ubi talas

\begin{tabular}{cccc}
\hline \multirow{2}{*}{ Konsentrasi Pati } & \multicolumn{3}{c}{ Jenis Plasticizer } \\
\cline { 2 - 4 } & Gliserol (P1) & Sorbitol (P2) & $\begin{array}{c}\text { Gliserol:Sorbitol 1:1 } \\
(\mathrm{P} 3)\end{array}$ \\
\hline T1 $(5 \%)$ & $1,710 \pm 0,071 \mathrm{bc}$ & $1,325 \pm 0,021 \mathrm{~d}$ & $0,595 \pm 0,120 \mathrm{f}$ \\
T2 $(6 \%)$ & $2,270 \pm 0,057 \mathrm{a}$ & $1,487 \pm 0,078 \mathrm{~cd}$ & $0,920 \pm 0,085 \mathrm{e}$ \\
T3 $(7 \%)$ & $1,935 \pm 0,078 \mathrm{~b}$ & $1,345 \pm 0,007 \mathrm{~d}$ & $0,700 \pm 0,028 \mathrm{ef}$ \\
\hline
\end{tabular}

Keterangan: huruf yang berbeda di belakang nilai rata-rata menunjukkan perbedaan yang nyata pada taraf kesalahan $5 \%(\mathrm{p}<0.05)$

Kuat tarik meningkat akibat adanya gaya intermolekul antar rantai pati tersebut (Hasanah, 2012). Kuat tarik terendah $(0,595 \pm 0,120 \mathrm{MPa})$ terdapat pada konsentrasi pati $5 \%$ yang tidak berbeda nyata dengan konsentrasi pati $7 \%$ dengan campuran plasticizer gliserol dan sorbitol. Hal ini disebabkan karena campuran melampaui titik jenuh sehingga molekul pemlastis yang berlebih berada pada fase tersendiri di luar fase pati dan akan menurunkan gaya intermolekuler antar rantai yang menyebabkan gerakan rantai lebih bebas (Hasanah, 2012).

Kriteria nilai kuat tarik menurut SNI plastik adalah 24,7-302 MPa (Nurlita et al., 2017), sedangkan menurut standar internasional ISO 527/ 1B sebesar 35.95 MPa. Dengan demikian, apabila dilihat dari nilai kuat tariknya, bioplastik yang dihasilkan dalam penelitian ini belum sesuai dengan nilai kuat tarik berdasarkan SNI dan standar internasional ISO 527/ 1B.

\section{Perpanjangan Saat Putus (Elongation at Break)}

Berdasarkan hasil analisis keragaman menunjukkan bahwa konsentrasi pati dan jenis plasticizer berpengaruh sangat nyata $(\mathrm{p}<0,01) \quad$ sedangkan interaksinya tidak berpengaruh nyata terhadap perpanjangan saat putus bioplastik pati ubi talas. Nilai perpanjangan saat putus bioplastik pati ubi talas berkisar antara $14,50 \pm 0,01-33,50 \pm 0,01$ (\%) yang dapat dilihat pada Tabel 2.

Tabel 2 menunjukkan bahwa rata-rata persen perpanjangan saat putus dari bioplastik ubi talas pada konsentrasi pati $5 \%$ menghasilkan nilai tertinggi yang berbeda nyata dengan $6 \%$ maupun $7 \%$. Sementara itu konsentrasi pati $6 \%$ memberikan nilai perpanjangan terendah yang berbeda nyata dengan lainnya. Tabel 2 juga menunjukkan bahwa rata-rata nilai perpanjangan saat putus tertinggi $(30,2 \pm 0,04 \%)$ dimiliki bioplastik ubi talas yang menggunakan plasticizer campuran gliserol dan sorbitol yang berbeda dengan lainnya sedangkan nilai rata-rata 
persen perpanjangan terendah dimiliki bioplastik ubi talas yang menggunakan plasticizer gliserol. Persentasi perpanjangan berbanding terbalik dengan kuat tarik. Hal ini dapat dilihat pada penggunaan konsentrasi pati 5,6 dan 7\% dengan plasticizer gliserol yang memiliki nilai kuat tarik tertinggi, namun nilai perpanjangan saat putus rendah dibandingkan perlakuan lainnya. Hal ini disebabkan zat pemlastis akan terletak diantara rantai polimer sehingga jarak antar rantai pati semakin renggang dan memudahkan pergerakan antar molekul yang menyebabkan meningkatnya nilai persen perpanjangan saat putus pada bioplastik yang dihasilkan (Afif et al., 2018).

Tabel 2. Nilai perpanjangan saat putus (\%) bioplastik dari pati ubi talas

\begin{tabular}{ccccc}
\hline \multirow{2}{*}{ Konsentrasi Pati } & \multicolumn{3}{c}{ Jenis Plasticizer } & \multirow{2}{*}{ Rata-rata } \\
\cline { 2 - 4 } & Gliserol (P1) & Sorbitol (P2) & $\begin{array}{c}\text { Gliserol:Sorbitol } \\
1: 1(\mathrm{P} 3)\end{array}$ & \\
\hline T1 $(5 \%)$ & $22,00 \pm 0,01$ & $27,00 \pm 0,03$ & $33,50 \pm 0,01$ & $27,50 \pm 0,05 \mathrm{a}$ \\
T2 $(6 \%)$ & $14,50 \pm 0,01$ & $19,50 \pm 0,01$ & $26,00 \pm 0,01$ & $20,00 \pm 0,05 \mathrm{c}$ \\
T3 (7\%) & $18,00 \pm 0,01$ & $23,00 \pm 0,01$ & $31,00 \pm 0,03$ & $24,00 \pm 0,06 \mathrm{~b}$ \\
\hline Rata-rata & $18,20 \pm 0,04 \mathrm{c}$ & $23,20 \pm 0,04 \mathrm{~b}$ & $30,20 \pm 0,04 \mathrm{a}$ & \\
\hline Keterangan: huruf yang berbeda di belakang nilai rata-rata menunjukkan perbedaan yang nyata pada taraf \\
kesalahan 5\% (p<0,05)
\end{tabular}

Kriteria nilai perpanjangan saat putus menurut SNI untuk plastik adalah 21-220\%. Berdasarkan standar plastik internasional (ASTM 5336) (Averous, 2009 dalam Epriyanti, 2015) besarnya persen perpanjangan saat putus untuk plastik Polycaprolactone (PCL) dari Inggris mencapai $>500 \%$. Besarnya persentase perpanjangan saat putus bioplastik yang dihasilkan dari penelitian ini belum memenuhi SNI dan standar yang digunakan oleh plastik PCL dari Inggris.

\section{Elastisitas (Modulus Young)}

Berdasarkan hasil analisis keragaman menunjukkan bahwa konsentrasi pati dan jenis plasticizer serta interaksinya berpengaruh sangat nyata $(\mathrm{p}<0.01)$ terhadap nilai elastisitas bioplastik dari pati ubi talas. Nilai elastisitas bioplastik dari pati talas berkisar antara $1,773 \pm 0,321-15,683 \pm 1,155$ MPa dapat dilihat pada Tabel 3.

Tabel 3. Nilai elastisitas (Modulus young) (MPa) bioplastik dari pati ubi talas

\begin{tabular}{cccc}
\hline \multirow{2}{*}{ Konsentrasi Pati } & \multicolumn{3}{c}{ Jenis Plasticizer } \\
\cline { 2 - 4 } & Gliserol (P1) & Sorbitol (P2) & $\begin{array}{c}\text { Gliserol:Sorbitol } \\
1: 1(\mathrm{P} 3)\end{array}$ \\
\hline T1 $(5 \%)$ & $7,799 \pm 0,823 \mathrm{c}$ & $5,013 \pm 0,321 \mathrm{de}$ & $1,773 \pm 0,321 \mathrm{f}$ \\
T2 $(6 \%)$ & $15,683 \pm 1,155 \mathrm{a}$ & $7,628 \pm 0,675 \mathrm{~cd}$ & $3,571 \pm 0,493 \mathrm{ef}$ \\
T3 $(7 \%)$ & $10,766 \pm 0,414 \mathrm{~b}$ & $5,860 \pm 0,391 \mathrm{cde}$ & $2,272 \pm 0,299 \mathrm{f}$ \\
\hline
\end{tabular}

Keterangan: huruf yang berbeda di belakang nilai rata-rata menunjukkan perbedaan yang nyata pada taraf kesalahan $5 \%(\mathrm{p}<0,05)$

Elastisitas dilakukan untuk mengetahui keelastisan suatu bahan yang dihasilkan. Nilai elastisitas diperoleh dari perbandingan antara kekuatan tarik terhadap elongasi (Arini, 2017). Tabel 3 menunjukkan bahwa nilai elastisitas tertinggi $(15,683 \pm 1,155$ $\mathrm{MPa}$ ) dari bioplastik pati ubi talas terdapat pada konsentrasi pati $6 \%$ dengan plasticizer gliserol. Sementara itu pada konsentrasi pati 5, 6 dan 7\% dengan campuran plasticizer gliserol dan sorbitol menunjukkan nilai elastisitas terendah $(1,773 \pm 0,321 \mathrm{MPa})$. Hal ini disebabkan karena plasticizer gliserol dan sorbitol yang bersifat saling melemahkan 
gaya ikatan antar molekuler yang berdekatan. Coniawati (2014) menjelaskan bahwa penurunan Modulus young ini terjadi karena titik jenuh telah terlampaui sehingga molekul-molekul plasticizer yang berlebihan berada di dalam fase tersendiri di luar fase polimer dan akan menurunkan gaya intermolekuler antar rantai yang menyebabkan gerakan rantai lebih bebas. Pada penelitian Darni dan Utami (2010) menyatakan bahwa nilai elastisitas berbanding lurus dengan nilai kuat tarik sedangkan berbanding terbalik dengan perpanjangan saat putus.

Berdasarkan standar plastik international ISO 527/1B besarnya nilai elastisitas (modulus young) untuk plastik adalah $6019 \mathrm{MPa}$. Besarnya nilai elastisitas bioplastik yang dihasilkan dari penelitian ini belum memenuhi standar plastik yang digunakan ISO 527/1B.

\section{Uji Pengembangan Tebal (Swelling)}

Berdasarkan hasil analisis keragaman menunjukkan bahwa konsentrasi pati dan jenis plasticizer serta interaksinya berpengaruh sangat nyata $(\mathrm{p}<0,01)$ terhadap nilai pengembangan tebal bioplastik dari pati ubi talas. Nilai uji pengembangan tebal bioplastik pati ubi talas berkisar antara $37,62 \pm 0,07-147,22 \pm 0,08(\%)$ dapat dilihat pada Tabel 4.

Tabel 4. Nilai pengembangan tebal (\%) bioplastik dari pati ubi talas

\begin{tabular}{cccc}
\hline \multirow{2}{*}{ Konsentrasi Pati } & \multicolumn{3}{c}{ Jenis Plasticizer } \\
\cline { 2 - 4 } & Gliserol (P1) & Sorbitol (P2) & Gliserol:Sorbitol 1:1 (P3) \\
\hline T1 (5\%) & $11,91 \pm 1,25 \mathrm{~h}$ & $114,05 \pm 0,22 \mathrm{c}$ & $62,12 \pm 0,25 \mathrm{e}$ \\
T2 (6\%) & $29,89 \pm 1,02 \mathrm{~g}$ & $126,84 \pm 0,72 \mathrm{~b}$ & $95,11 \pm 0,43 \mathrm{~d}$ \\
T3 (7\%) & $37,62 \pm 0,07 \mathrm{f}$ & $147,22 \pm 0,08 \mathrm{a}$ & $126,23 \pm 0,52 \mathrm{~b}$ \\
\hline
\end{tabular}

Keterangan: huruf yang berbeda di belakang nilai rata-rata menunjukkan perbedaan yang nyata pada taraf kesalahan $5 \%(\mathrm{p}<0,05)$

Tabel 4 menunjukkan bahwa konsentrasi pati yang semakin tinggi menyebabkan nilai pengembangan tebal yang semakin besar pula. Hal ini disebabkan kecenderungan pati yang memiliki lebih banyak gugus hidroksil $(\mathrm{OH})$. Berdasarkan Tabel 4. dapat dilihat bahwa tingkat ketahanan air yang paling rendah $(147,22 \pm 0,08 \%)$ terdapat pada konsentrasi pati $7 \%$ dengan plasticizer sorbitol, sedangkan ketahanan air tertinggi $(11,91 \pm 1,25 \%)$ terdapat pada konsentrasi pati $5 \%$ dengan plasticizer gliserol. Semakin tinggi pengembangan tebal pada suatu plastik maka ketahanan airnya semakin rendah dan akan terjadi penggembungan (swelling) pada sampel. Tingginya pengembangan tebal pada penggunaan plasticizer sorbitol dikarenakan sorbitol merupakan plasticizer yang bersifat lebih hidrofilik sehingga ikatan polimer yang terbentuk antara campuran (bioplastik patisorbitol) memiliki porositas yang lebih tinggi dan menyebabkan kemampuan mengikat air yang lebih besar. Menurut Goldberg dan Williams (1991) dalam Sitompul dan Zubaidah (2017) perbedaan berat molekul (BM) yang dimiliki masing-masing plasticizer dapat menyebabkan peningkatan kadar air. Semakin besar BM menyebabkan terdapatnya celah yang lebih besar antar molekul yang dapat disisipi oleh molekul air sehingga menyebabkan peningkatan air. Diketahui bahwa sorbitol memiliki BM yang lebih besar daripada gliserol.

Berdasarkan standar plastik internasional (EN 317) besarnya nilai pengembangan tebal (swelling) untuk plastik adalah sebesar $1,44 \%$. Besarnya nilai penyerapan air bioplastik yang dihasilkan dari penelitian ini belum memenuhi standar 
plastik Internasional.

\section{Biodegradasi}

Berdasarkan hasil analisis keragaman menunjukkan bahwa rata-rata jenis plasticizer berpengaruh sangat nyata $(\mathrm{p}<0,01)$ sedangkan konsentrasi pati dan interaksinya tidak berpengaruh nyata terhadap nilai biodegradasi bioplastik dari pati ubi talas. Nilai uji biodegradasi berkisar antara 6-7 hari yang disajikan pada Tabel 5, sedangkan tabel laju susut bobot bioplastik terhadap waktu degradasi dapat dilihat pada Tabel 6.

Tabel 5. Nilai uji biodegradasi (hari) bioplastik dari pati ubi talas

\begin{tabular}{ccccc}
\hline \multirow{2}{*}{ Konsentrasi Pati } & \multicolumn{3}{c}{ Jenis Plasticizer } & \multirow{2}{*}{ Rata-rata } \\
\cline { 2 - 4 } & Gliserol (P1) & Sorbitol (P2) & $\begin{array}{c}\text { Gliserol:Sorbitol } \\
1: 1(\mathrm{P} 3)\end{array}$ & \\
\hline T1 $(5 \%)$ & $7,00 \pm 0,00 \mathrm{a}$ & $6,00 \pm 0,00 \mathrm{a}$ & $7,00 \pm 0,00 \mathrm{a}$ & $6,67 \pm 0,52 \mathrm{a}$ \\
T2 $(6 \%)$ & $7,00 \pm 0,00 \mathrm{a}$ & $6,00 \pm 0,00 \mathrm{a}$ & $7,00 \pm 0,71 \mathrm{a}$ & $6,50 \pm 0,55 \mathrm{a}$ \\
T3 (7\%) & $7,00 \pm 0,00 \mathrm{a}$ & $6,00 \pm 0,00 \mathrm{a}$ & $7,00 \pm 0,00 \mathrm{a}$ & $6,67 \pm 0,52 \mathrm{a}$ \\
\hline Rata-rata & $7,00 \pm 0,00 \mathrm{a}$ & $6,00 \pm 0,00 \mathrm{~b}$ & $6,83 \pm 0,41 \mathrm{a}$ & \\
\hline
\end{tabular}

Keterangan: huruf yang sama dibelakang nilai rata-rata menunjukkan tidak ada perbedaan yang nyata pada taraf kesalahan $5 \%(\mathrm{p}<0,05)$

Tabel 6. Koefisien regresi dan determinasi hubungan persen laju susut bobot terhadap waktu degradasi bioplastik pati ubi talas

\begin{tabular}{lcc}
\hline \multicolumn{1}{c}{ Perlakuan } & Koef. Regresi $(\mathrm{y})$ & Koef. Determinasi $\left(\mathrm{R}^{2}\right)$ \\
\hline Pati 5\% ; Gliserol & $10,440 \mathrm{x}+1,3353$ & 0,9727 \\
Pati 5\% ; Sorbitol & $13,762 \mathrm{x}+2,0219$ & 0,9933 \\
Pati 5\% ; Gliserol:Sorbitol (1:1) & $11,515 \mathrm{x}+1,0738$ & 0,9958 \\
Pati 6\% ; Gliserol & $10,952 \mathrm{x}-3,8803$ & 0,9863 \\
Pati 6\%; Sorbitol & $14,854 \mathrm{x}-5,5858$ & 0,9647 \\
Pati 6\%; Gliserol:Sorbitol (1:1) & $13,366 \mathrm{x}-6,3521$ & 0,9905 \\
Pati 7\% ; Gliserol & $11,328 \mathrm{x}-4,4582$ & 0,9931 \\
Pati 7\% ; Sorbitol & $13,062 \mathrm{x}+4,4486$ & 0,9917 \\
Pati 7\%; Gliserol:Sorbitol (1:1) & $11,305 \mathrm{x}+1,6425$ & 0,9957 \\
\hline
\end{tabular}

Tabel 5 menunjukkan bahwa bioplastik dapat terdegradasi dalam waktu 6-7 hari. Hal ini dikarenakan komponen penyusun bioplastik merupakan bahan alam. Menurut Darni dan Utami (2010) bioplastik mudah terdegradasi karena bioplastik yang dihasilkan mengandung gugus fungsi hidroksil $(\mathrm{O}-\mathrm{H})$, karbonil $(\mathrm{C}=\mathrm{O})$ dan karboksil (C-O) ester. Gugus tersebut memiliki sifat hidrofilik sehingga molekul air dapat mengakibatkan mikroorganisme pada lingkungan memasuki matriks plastik tersebut. Tabel 5 juga menunjukkan bahwa rata-rata kemampuan biodegradasi tercepat dimiliki bioplastik menggunakan plasticizer sorbitol. Hal ini disebabkan karena bioplastik pada campuran pati-sorbitol membentuk ikatan hidrogen yang bersifat lebih lemah dibandingkan dengan bioplastik pada campuran pati-gliserol sehingga membuat bioplastik lebih cepat terurai. Berdasarkan Tabel 6. menunjukkan bahwa bioplastik pati ubi talas dengan jenis plasticizer sorbitol memiliki nilai slope yang lebih tinggi dibandingkan perlakuan lainnya. Laju susut bobot tertinggi terdapat pada konsentrasi $6 \%$ dengan plasticizer sorbitol dengan persamaan regresi $\mathrm{y}=14,854 \mathrm{x}-5,5858$ dan laju susut 
bobot terendah terdapat pada konsentrasi 5\% dengan plasticizer gliserol dengan persamaan regresi $y=10,44 x+1,3353$. Hal ini berarti semakin tinggi nilai slope maka semakin cepat bioplastik terdegradasi, sebaliknya semakin rendah nilai slope maka semakin lambat bioplastik terdegradasi.

Berdasarkan standar plastik internasional (ASTM5336) (Averous, 2019 dalam Epriyanti, 2015) lamanya kemampuan biodegradasi untuk plastik PLA dari Jepang dan PCL dari Inggris membutuhkan waktu 60 hari untuk dapat terurai keseluruhan (100\%). Lamanya kemampuan degradasi yang dihasilkan dari penelitian ini adalah dalam waktu 6-7 hari. Kemampuan terdegradasi tersebut telah memenuhi standar yang digunakan oleh plastik PLA Jepang maupun PCL dari Inggris.

\section{Gugus Fungsi}

Uji Fourier Transform Infrared Spectroscopy digunakan untuk mengidentifikasi bahan kimia yang terkandung dalam suatu bahan polimer (Darni, 2010). Spektrum inframerah bioplastik menunjukkan bilangan gelombang 3678,$25 ; \quad 3562,52 ; \quad 1680,00 ; \quad 1496,76$; 1186,22; 896,90; 686,66; 570,93; 497,63 $\mathrm{cm}^{-}$ ${ }^{1}$. Hasil analisis spektrofotometer FTIR (Fourier Transform Infra Red), disajikan dalam Gambar 2.

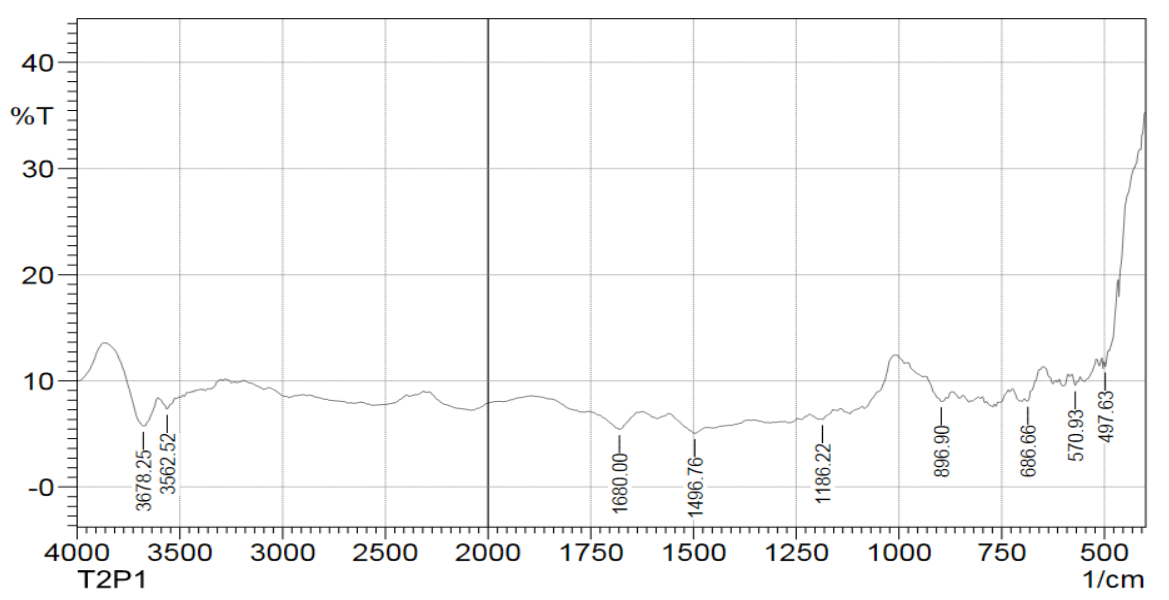

Gambar 2. Analisis FTIR bioplastik pati ubi talas

Tabel 6. Hasil bilangan gelombang dan gugus fungsi pada bioplastik pati ubi talas

\begin{tabular}{c|c}
\hline Bilangan Gelombang $\left(\mathrm{cm}^{-1}\right)$ & Gugus Fungsi \\
\hline $3100-3700$ & $\mathrm{O}-\mathrm{H}$ alkohol \\
$1550-1950$ & $\mathrm{C}=\mathrm{O}$ ester \\
$1430-1650$ & $\mathrm{C}=\mathrm{C}$ aromatic \\
$1000-1300$ & $\mathrm{C}-\mathrm{O}$ ester \\
$600-900$ & $\mathrm{C}-\mathrm{H}$ aromatik \\
$<600$ & $-\left(\mathrm{CH}_{2}\right) \mathrm{n}$ \\
\hline
\end{tabular}

Gambar 2. menunjukkan hasil analisis gugus fungsi hasil sintesis bioplastik pada konsentrasi pati $6 \%$ dengan plasticizer gliserol yang merupakan bioplastik dengan karakteristik sifat mekanik terbaik. Hasil analisa menunjukkan adanya serapan gugus hidroksil (O-H) dari regangan alkohol pada bilangan gelombang 3678.25 dan 3562.52 $\mathrm{cm}^{-1}$ dan gugus karbonil $(\mathrm{C}=\mathrm{O})$ dari regangan ester pada bilangan gelombang $1680.00 \mathrm{~cm}^{-1}$ (Pavia et al., 2001 dalam Sirait, 2015). Sementara itu, pada bilangan gelombang 
$1496.76 \mathrm{~cm}^{-1}$ menunjukkan adanya gugus $\mathrm{C}=\mathrm{C}$ aromatik (Stuart, 2004 dalam Radhiyatullah et al., 2015). Menurut Pavia et al., (2001) dalam Sirait (2015), menunjukkan adanya keberadaan gugus karboksil $(\mathrm{C}-\mathrm{O})$ dari regangan ester pada bilangan gelombang $1186.22 \mathrm{~cm}^{-1}$. Bilangan gelombang 896.90 dan $686.66 \mathrm{~cm}^{-1}$ menunjukkan adanya gugus C-H aromatic dan pada bilangan gelombang dibawah $600 \mathrm{~cm}^{-1}$ menunjukkan adanya senyawa hidrokarbon lain seperti $-\left(\mathrm{CH}_{2}\right) n$ (Thu, 2015). Uraian tersebut menjelaskan bahwa bioplastik pati ubi talas mengandung gugus fungsi hidroksil $(\mathrm{O}-\mathrm{H})$, karbonil $(\mathrm{C}=\mathrm{O}), \mathrm{C}=\mathrm{C}$ aromatik, karboksil $(\mathrm{C}-\mathrm{O}), \mathrm{C}-\mathrm{H}$ aromatik dan hidrokarbon $-\left(\mathrm{CH}_{2}\right)$ n. Artinya, keberadaan gugus fungsi tersebut mempunyai potensi untuk berikatan dengan senyawa lain dalam membentuk ikatan rantai bercabang maupun ikatan silang (crosslink) sehingga memungkinkan dalam menghasilkan polimer yang kuat. Menurut Darni dan Utami (2010) Ikatan kimia yang kuat bergantung pada jumlah ikatan molekul dan jenis ikatannya. Semakin banyak ikatan antar molekul semakin kuat bahan yang dihasilkan.

\section{KESIMPULAN DAN SARAN}

\section{Kesimpulan}

Berdasarkan penelitian yang telah dilakukan maka dapat disimpulkan beberapa hal sebagai berikut :

1. Konsentrasi pati dan jenis plasticizer berpengaruh sangat nyata terhadap kuat tarik, perpanjangan saat putus, elastisitas dan pengembangan tebal tetapi jenis plasticizer berpengaruh tidak nyata terhadap nilai biodegradasi. Interaksi antar perlakuan berpengaruh sangat nyata terhadap elastisitas dan pengembangan tebal, berpengaruh nyata pada kuat tarik serta berpengaruh tidak nyata pada perpanjangan saat putus dan biodegradasi.

2. Karakteristik terbaik dimiliki bioplastik pada perlakuan konsentrasi pati $6 \%$ dengan plasticizer gliserol dengan nilai kuat tarik sebesar 2,270 $\pm 0,057 \mathrm{MPa}$, perpanjangan saat putus $14,50 \pm 0,01 \%$, elastisitas $15,683 \pm 1,155 \mathrm{MPa}$, uji pengembangan tebal $29,89 \pm 1,02 \%$ dan kemampuan biodegradasi 6-7 hari. Hasil analisis FTIR menunjukkan adanya gugus fungsi hidroksil $(\mathrm{O}-\mathrm{H})$, karbonil $(\mathrm{C}=\mathrm{O}), \mathrm{C}=\mathrm{C}$ aromatik, karboksil $(\mathrm{C}-\mathrm{O})$, $\mathrm{C}-\mathrm{H}$ aromatik dan hidrokarbon $-\left(\mathrm{CH}_{2}\right) \mathrm{n}$ pada bioplastik pati ubi talas. Bioplastik yang dihasilkan dalam penelitian ini belum memenuhi kriteria mekanik kuat tarik, elastisitas dan pengembangan tebal.

\section{Saran}

Perlu dilakukan penelitian lebih lanjut dalam mengembangkan dan menemukan formulasi baru dengan mencari konsentrasi plasticizer untuk meningkatkan nilai kuat tarik bioplastik dari pati ubi talas.

\section{DAFTAR PUSTAKA}

Afif, M. N. Wijayanti dan S. Mursiti. 2018. Pembuatan bioplastik dari pati biji alpukat-kitoson dengan plasticizer sorbitol. Indonesian Journal of Chemical Science. 7(2):102-109.

Agustin, Y.E. dan K.S. Padmawijaya. 2016. Sintesis bioplastik dari kitosan-pati kulit pisang kapok dengan penambahan zat aditif. Jurnal Teknik Kimia. 10(2):40-48.

Arini, D., M. Syahrul Ulum dan Kasman. 2017. Pembuatan dan pengujian sifat mekanik platik biodegradable berbasis tepung bji durian. Journal of Science and Technology. 6(3):276-283. 
ASTM D638: Standart Test Method for Tensile Properties of Plastics. American Society for Testing and Materials.

Averous, L. 2004. Biodegradable multiphase systems based on plasticized starch. J Macromol Sci. 12(2):123-130.

Coniwanti, P. L. Laila dan M.R. Alfira. 2014. Pembuatan film plastik biodegradable dari pati jagung dengan penambahan kitosan dan pemlastis gliserol. Jurnal Teknik Kimia. 20(4):22-30.

Dai, H., P.R. Chang F. Geng, J. Yu dan X. Ma. 2010. Preparation and properties of starch based film using n,n-bis(2hydroxyethyl) formamide as a new plasticizer. Carbohydrate Polymers. 79(2):306-311.

Darni, Y. dan H. Utami. 2010. Studi pembuatan dan karakteristik sifat mekanik dan hidrofobisitas bioplastik dari pati sorgum. Jurnal Rekayasa Kimia dan Lingkungan, 7(4):88-93.

EN 317:1993. Particleboards and Fibreboards. Determination of Swelling in Thickness After Immersion Water. British-Adopted European Standard.

Epriyanti, N.M.H. 2015. Pengaruh Suhu dan Lama Pengeringan terhadap Karakteristik Komposit Plastik Biodegradable dari Pati Kulit Singkong dan Kitosan. Skripsi. Tidak dipublikasikan. Program Studi Teknologi Industri Pertanian, Fakultas Teknologi Pertanian, Unud, Bukit Jimbaran.

Gibson, R.F. 1994. Principles of Composite Material Mechanics. Mc. Graw-Hill, Inc. Singapore.

Harsojuwono, B.A. dan I.W. Arnata. 2016.
Karakteristik fisik dan mekanik bioplastik (studi konsentrasi tapioka dan perbandingan campuran pemlastis). Media Ilmiah Teknologi pangan. 3(1):1-7.

Hasanah, N. 2012. Pembuatan dan Pencitraan Plastik Pati Tapioka dengan Pemlastis Gliserol. Skripsi. Departemen Kimia, Fakultas Matematika dan Ilmu Pengetahuan Alam, Institut Pertanian Bogor, Bogor.

Hidayanti, S., A.S. Zuidar dan A. Ardiani. 2015. Aplikasi sorbitol pada produksi biodegradable film dari nata de cassava. Reaktor. 15(3):196-204.

ISO 527/ 1B: Plastics - Determination of Tensile Properties. International Organization for Standart, 2012.

Liu Z. dan J. H. Han. 2006. Film forming Characteristics of starches. Journal of Food Science. 70(1):31-36.

Nahwi, N.F. 2016. Analisis Pengaruh Penambahan Plasticizer Gliserol pada Karakteristik Edible Film dari Pati Kulit Pisang Raja, Tongkol Jagung dan Bonggol Enceng Gondok. Skripsi. Program Studi Kimia, Fakultas Sains dan Teknologi, Universitas Islam Negeri Maulana Malik Ibrahim, Malang.

Nurdini, L., Hendriyana, H. Fansyuri dan T. Wibowo. 2018. Pengaruh penambahan pati umbi kayu dalam pembuatan bioplastik dari pati sukun. Prosiding Seminar Nasional Teknik Kimia.

Radhiyatullah, A., N. Indriani, M. Hendra dan S. Ginting. 2015. Pengaruh berat pati dan volume plasticizer terhadap karakteristik film bioplastik pai kentang. Jurnal Teknik Kimia. 4(3):3539. 
Rahmawati, W., Y.A. Kusumastuti dan N. Aryanti. 2012. Karakteriasi pati talas (Colocasia esculenta (L) Schott) sebagai alternatif sumber pati industri di Indonesia. Jurnal Teknologi Kimia dan Industri. 1(1):347-351.

Setiani, W., T. Sudiarti dan L. Rahmidar. 2013. Preparasi dan karakterisasi edible film dari poliblend pati sukun-kitosan. Valensi. 3(2):100-109.

Sinaga, R.F., G.M. Ginting., M.H.S. Ginting dan R. Hasibuan. 2014. Pengaruh penambahan gliserol terhadap sifat kekuatan tarik dan pemanjangan saat putus bioplastik dari pati umbi talas. Jurnal Teknik Kimia. 3(2):19-24.
Sirait. T.P. 2015. Pengaruh Penambahan Kitoson terhadap Karakteristik Bioplastik dari Pati Talas dengan menggunakan Plasticizer Gliserol. Skripsi. Departemen Teknik Kimia, Fakultas Teknik, Universitas Sumatera Utara, Medan.

Sitompul, A.J.W.S dan E. Zubaidah. 2017. Pengaruh jenis dan konsentrasi plasticizer terhadap sifat fisik edible film kolang kaling (Arenga pinnata). Jurnal Pangan dan Agroindustri. 5(1):13-25. 